\title{
FOREIGN EXPERIENCE IN THE INDIVIDUALS TAX CONTROL
}

S.V. Salmina

Kazan Federal University, Institute of Management, Economics and Finance, Kazan, Russia

\section{A.M. Tufetulov}

Kazan Federal University, Institute of Management, Economics and Finance,

Kazan, Russia

V.I. Nasyrova

Kazan Federal University, Institute of Management, Economics and Finance,

Kazan, Russia

A.R. Khafizova

Kazan Federal University, Institute of Management, Economics and Finance,

Kazan, Russia

E-mail: svetasv21@yandex.ru

Recepción: 05/08/2019 Aceptación: 18/09/2019 Publicación: 23/10/2019

\section{Gitación sugerida:}

Salmina, S.V., Tufetulov, A.M., Nasyrova, V.I. y Khafizova, A.R. (2019). Foreign experience in the individuals tax control. 3C TIC. Cuadernos de desarrollo aplicados a las TIC. Edición Especial, Octubre 2019, 286-299. doi: https://doi.org/10.17993/3ctic.2019.83-2.286-299

Suggested citation:

Salmina, S.V., Tufetulov, A.M., Nasyrova, V.I. \& Khafizova, A.R. (2019). Foreign experience in the individuals tax control. 3C TIC. Cuadernos de desarrollo aplicados a las TIC. Special Issue, October 2019, 286-299. doi: https://doi.org/10.17993/3ctic.2019.83-2.286-299 


\section{ABSTRACT}

The exercise of control over the collection of taxes is one of the key links ensuring the replenishment of the treasury of the budget of any state. Therefore, a huge role is played by the tax authorities of the country. It is thanks to them that reliable and timely collection of taxes is carried out, the functions assigned to the tax system are implemented. Tax control is aimed at all subjects of the economy: both legal entities and individuals. Tax control is carried out in order to identify tax offenses, as well as ensuring the inevitability of bringing to justice for tax offenses. In order to implement these goals within the framework of tax control, it is necessary to ensure that checks are made for the correctness of the calculation and payment of taxes, the prevention of tax violations and the provision of compensation for damage caused to the state as a result of non-fulfillment by taxpayers of their duties. In this study, the authors consider the comparative characteristics of the tax systems of foreign countries and the Russian Federation. The analysis of the performance of on-site tax audits of individuals for 2014-2018 has been carried out. The authors concluded that some foreign trends in tax control could be relevant in Russia. After all, the constant development of forms and methods, as well as the very basis of tax control - the tax base, allows us to constantly improve the entire tax system in Russia, increase tax revenues and reduce the taxpayers' debt.

\section{KEYWORDS}

Tax, Taxation, Individuals, Tax Control, Foreign Experience. 


\section{INTRODUCTION}

Tax control over individuals always needs constant improvement, increasing productivity, maintaining financial stability and keeping up with time. Due to the fact that taxes and fees are a significant source of the revenue part of the state budget, it is tax control that acts as a priority for tax authorities. Therefore, the introduction of international developments can meet these requirements and introduce innovations and peculiarities to the tax control authorities of the Russian Federation. Consider the tax control of several countries, such as Japan, Germany and the United States. The choice of compared countries is due, first of all, to the diversity of their location. In addition, the tax system of each country is distinguished not only by its uniqueness, but also by its efficiency.

\section{METHODOLOGY}

In conducting the study, the methods of comparison and generalization, methods of statistical analysis and methods of analogy for determining risks were used.

\section{RESULTS AND DISCUSSION}

Speaking of Japan, it should be said that this is one of the most highly developed countries in the world in the field of economics and technology. One of the features of the tax system of Japan is that in this country the highest proportion of income taxes is compared with developed countries (Mityurnikova \& Revyakina, 2013, p. 30). It is also worth noting that the most significant income to the state comes from the income tax on individuals and legal entities, which in total exceeds 56\% of all tax revenues. For individuals in Japan, there is a progressive income tax scale, the tax rates for personal income are in the range from $10 \%$ to $50 \%$.

A detailed comparison of the main characteristics of the tax system of Japan and Russia, as well as the administrative authorities of these countries, is reflected in Table 1. 
Table 1. Comparative characteristics of the tax systems of Russia and Japan.

\begin{tabular}{|c|c|c|}
\hline Indicators & Russia & Japan \\
\hline $\begin{array}{c}\text { Tax rate } \\
\text { Ratios of direct and } \\
\text { indirect taxes, } \%\end{array}$ & Three level system & Three level system \\
\hline $\begin{array}{c}\text { Personal income tax\% } \\
\text { The revenue part of the } \\
\text { country's budget, \% }\end{array}$ & $45 / 55$ & $60 / 40$ \\
\hline $\begin{array}{c}\text { Progressive taxation } \\
\text { Tax management }\end{array}$ & 90 tax / 10 non-tax & 10, 20,30,37 tax / 15 non-tax \\
\hline $\begin{array}{c}\text { The Central Authority of the } \\
\text { state tax system }\end{array}$ & The Federal Tax Service & $\begin{array}{c}\text { Central Office - National Tax } \\
\text { Administration }\end{array}$ \\
\hline
\end{tabular}

Source: (Yegorov, 2017, p. 62).

In addition to the similar characteristics of the tax systems of the compared countries, various should be noted. These include the discrepancy in the organization of tax control expressed in various forms of responsibility (Solovyova \& Shevchenko, 2013, p. 49). Thus, in Russia, responsibility for violation of legislation on taxes and fees by individuals is divided into tax, administrative and criminal, provided in accordance with the Tax Code, the Code on Administrative Offenses and the Criminal Code. Whereas in Japan there is only tax and criminal liability provided for by acts of criminal administrative legislation.

Comparing the elements of the implementation of tax control over individuals in Russia and Japan, we can conclude that the Japanese tax system is more centralized, the administration is more rigid and limited by law. However, this does not at all indicate that the Federal Tax Service of Russia is not regulated by the norms of the law. The Russian tax authorities are more able to rely on an individual approach to each taxpayer, and therefore a greater likelihood of effective action. A comparison of the tax control systems of Japan and Russia also suggests that the state system is based primarily on the mentality of the country.

If you compare the tax system of Russia and the United States of America, you can also find many similar and excellent features. An interesting fact in this case is that the degree of compliance with the law in the United States is one of the highest in the world, the population pays about $83 \%$ of all taxes voluntarily 
and in accordance with the relevant provisions of the law (Gerb, 2015, p. 103). This demonstrates the good quality of the system of informing taxpayers about tax legislation and, at the same time, about sanctions that may follow in case of illegal behavior. In addition, such an indicator of taxpayers may indicate the peculiarities of the mentality of the country. Based on this consideration of the features of control in the United States will be important for comparison and analysis. The main provisions and aspects of the tax system are reflected in Table 2 .

Table 2. Comparative characteristics of the tax systems of Russia and the United States.

\begin{tabular}{|c|c|c|}
\hline Indicators & Russia & USA \\
\hline Tax rate & Three level system & Three level system \\
\hline $\begin{array}{c}\text { Personal income tax } \% \\
\text { Progressive taxation }\end{array}$ & 13 & $0,10,15,25,28,33,35,39.6$ \\
\hline Tax management & - & Progressive system \\
\hline $\begin{array}{c}\text { The Central Authority of the } \\
\text { state tax system }\end{array}$ & The Federal Tax Service & The Internal Revenue Service \\
\hline
\end{tabular}

The Central Authority of the state tax system in the United States at the federal level is the Internal Revenue Service (SVD), which is controlled by the Ministry of Finance. At the state level, state tax services act as a similar body. In addition, at the federal level under the SVD, the General Directorate for Tax Investigations operates, dealing with tax investigations and carrying out operational-search measures against unfair taxpayers.

Comparing the activities of the tax authorities of the United States and Russia, one can notice the fact that in these countries the interaction with taxpayers is actively developing. Interestingly, in the States, such assistance includes counseling through call centers, direct contact, the use of booklets with instructions for filling out declarations. In addition, there is a helpline in the USA that any resident can call and express concerns, suspicions, or reliable evidence of tax legislation (Morozov, 2009, p. 69). This indicates a high level of interaction between 
taxpayers and tax authorities. Mutual assistance can be one of the key reasons why the level of voluntariness in paying taxes among US citizens far exceeds that in other countries.

The next country in question is Germany. Here, the tax control is entrusted to the tax police of the country "Steufa". The most significant type of income in Germany, as in many other countries, are taxes. In this regard, special attention is paid to tax control. Consider the main provisions on the administration of tax policy, as well as the features of taxation in Germany, as reflected in Table 3.

Table 3. Comparative characteristics of the tax systems of Russia and Germany.

\begin{tabular}{|c|c|c|}
\hline Indicators & Russia & Germany \\
\hline Tax rate & Three level system & Three level system \\
\hline $\begin{array}{c}\text { Personal income tax\% } \\
\text { Progressive taxation }\end{array}$ & 13 & $\begin{array}{c}0,14,42,45 \\
\text { Tax management }\end{array}$ \\
$\begin{array}{c}\text { The Central Authority of the } \\
\text { state tax system }\end{array}$ & Ministry of Finance & $\begin{array}{c}\text { German Federal Ministry of } \\
\text { Finance }\end{array}$ \\
\hline
\end{tabular}

In Germany, the level of tax collection reaches $90 \%$, and tax evasion is an extremely unusual phenomenon for the Germans. Perhaps this is due to heightened legal awareness of citizens, and possibly the fact that tax crimes are included in the list of those who are criminally prosecuted by the tax police. In addition, in Germany there is a detailed and detailed legislation in the field of tax control. This leads to a reduction in misunderstanding, and accordingly, disputes between tax authorities and taxpayers. In addition to the above factors, it should be noted that it is an important fact that the banking system, the use of new technologies in tax services, the exchange of information between various services and government agencies - all this is at a sufficiently high and developed level.

Thus, comparing the tax control systems in Germany and Russia, it can be concluded that a number of features of the German system are repeated in the Russian one. In addition, they do not differ much from the characteristics 
considered as a result of the analysis of the previous three countries. Of course, in each country there are certain features that can be introduced into the tax control system of our country to further increase efficiency. However, one should consider the mentality of our country and the fact that not all the features can be taken from us. It is also worth noting that the tax control of most countries has similar features due to globalization and the emergence of new international projects, according to which member states should have a similar system of taxation and control. Therefore, the foreign experience of organizing tax control is relevant only in some specific areas of such control, and only considering the features of our own tax system.

Currently, foreign countries exercise tax control over individuals, combining three important aspects presented in Figure 1.

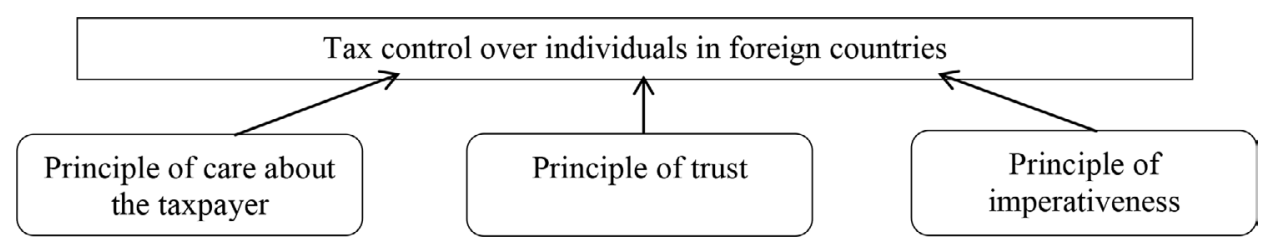

Figure 1. Principles on which tax control for individuals in foreign countries is based.

Thus, in many foreign countries with a stable tax system, since the end of the last century, tax authorities have been reformed. Many developed countries are modernizing their relations with taxpayers: in addition to the traditional "stick" (enforcing tax laws through various sanctions), the "carrot" has become widely used, that is, providing the taxpayer with the necessary services. As a service, tax advice, taxpayer training on how to prepare tax reports, the provision of other information and the provision of other assistance are offered. As the tax authorities of foreign countries implement the principle of caring for the taxpayer in the process of tax control over individuals, is presented in Table 4. 
Table 4. The implementation of the principle of care for the taxpayer in some foreign countries

\begin{tabular}{|c|c|c|}
\hline Characteristic & USA & Sweden \\
\hline $\begin{array}{c}\text { Assist taxpayers } \\
\text { in completing } \\
\text { declarations }\end{array}$ & $\begin{array}{l}\text { Each of the tax forms in the United } \\
\text { States contains detailed instructions } \\
\text { for filling it out. More than } 100 \\
\text { types of free brochures containing } \\
\text { information on various issues } \\
\text { related to tax declaration are issued } \\
\text { annually. One of these brochures } \\
\text { contains a complete catalog of free } \\
\text { services provided by tax authorities. } \\
\text { Instructions for completing } \\
\text { declarations can also be obtained } \\
\text { via an automated telephone system } \\
\text { or by calling a local telephone } \\
\text { number. In many libraries there are } \\
\text { videos with instructions for filling out } \\
\text { tax forms. }\end{array}$ & $\begin{array}{l}\text { Such a practice is widespread as } \\
\text { the independent preparation of tax } \\
\text { declarations for taxpayers, who then } \\
\text { receive this declaration through secure } \\
\text { channels of communication and can either } \\
\text { accept it or make their own changes and } \\
\text { additions. In the first case, it is enough for } \\
\text { them to confirm this declaration using an } \\
\text { electronic signature mechanism; in the } \\
\text { second case, they need to get in touch with } \\
\text { the tax service and provide the necessary } \\
\text { documentary evidence to substantiate the } \\
\text { proposed amendments and changes. }\end{array}$ \\
\hline
\end{tabular}

As can be seen from Table 4, foreign countries are currently building a system of such tax control, in which there is rationalization and simplification of tax procedures. And this is done both to simplify the work and optimize the working time of tax authorities, and to simplify and facilitate taxpayers. Therefore, a simplified approach to the collection and processing of tax reports is becoming more and more common in foreign countries. In this regard, in Sweden and Finland the tax authorities independently fill in declarations for individuals, and in the USA the tax authorities provide a wide range of tax services aimed at voluntary fulfillment of tax obligations. At the border of concern for the taxpayer and the imperativeness of tax control is the trust between taxpayers-individuals and tax authorities in foreign countries. This principle of trust is reflected in the existence of the institution of the fiscal rescript and the development of automated information systems of tax authorities, which is clearly reflected in Table 5.

Table 5. The implementation of the principle of trust in the implementation of tax control over individuals in foreign countries.

\section{Rescripcion Fiscal}

The taxpayer has the right to send a request about the legality of the proposed operation and to receive tax advice. The decision is mandatory for both the tax authorities and the taxpayer and is not subject to change.

USA The tax authority gives a written response to the taxpayer who made a preliminary request for the transaction, which he intends to conclude. 


\begin{tabular}{|c|c|}
\hline \multicolumn{2}{|r|}{ Rescripcion Fiscal } \\
\hline Sweden & $\begin{array}{c}\text { The tax law commission issues a preliminary opinion on the tax consequences } \\
\text { of a transaction. Preliminary detention is mandatory for tax authorities and is } \\
\text { applied provided that the taxpayer wishes this. }\end{array}$ \\
\hline Israel & $\begin{array}{l}\text { The taxpayer can ask for advice before the conclusion of the transaction, during } \\
\text { and after its completion, and the main condition is to file a request for a tax } \\
\text { decision before the deadline for the annual declaration. }\end{array}$ \\
\hline Germany & $\begin{array}{l}\text { The rescript procedure is limited to advising taxpayers on payroll tax, customs } \\
\text { duties, or assessing actual situations in connection with fiscal control. Published } \\
\text { positions expressed by the tax administration become mandatory for it, but do } \\
\text { not impose restrictions on the court. }\end{array}$ \\
\hline \multicolumn{2}{|r|}{ Automated information systems and technologies } \\
\hline USA & $\begin{array}{l}\text { To facilitate contact with taxpayers, a special computer program called Tele-File } \\
\text { has been introduced, which allows you to receive data from them by phone. } \\
\text { According to these data, within } 10 \text { minutes the program calculates the amount of } \\
\text { taxable income of a particular taxpayer and the amount of income tax due from } \\
\text { it. }\end{array}$ \\
\hline Australia & $\begin{array}{l}\text { All organizations of the country are registered through the website by electronic } \\
\text { contactless method within one day. Now the country is switching to the mode of } \\
\text { registering individual taxpayers online. }\end{array}$ \\
\hline
\end{tabular}

Source: (Elkina, 2014, p. 141).

Table 5 shows how a very interesting system of the institution of preliminary tax control and regulation is implemented in practice in some countries. Its meaning consists in the taxpayer agreeing with the tax authority the tax consequences of transactions before they are made. It is worth noting that, especially in Europe and the USA, the institute of preliminary tax regulation (it is also called the fiscal rescript) is a common form of tax control. The fiscal rescript is implemented in the course of signing tax agreements or receiving individual consultations (Solovyova \& Shevchenko, 2013, p. 66).

Speaking about the tax control system of individuals abroad, it is necessary to note the active use by the tax services of information technologies in interaction with taxpayers-individuals, which is also reflected in Tables 1, 2, 4 and which also builds on the principle of trust between the tax authority and the taxpayer. The overwhelming number of tax services in developed countries has specialized data processing centers (tax returns and tax payments). In data processing centers, the main work takes place with tax declarations of taxpayers-individuals at the primary tax control stage: when accepting declarations, processing them, comparing the information contained in them with other available data and directly transferring 
the results to the territorial tax authorities for subsequent control. Also, in many countries, certain services are provided by the tax authority for citizens to file tax returns electronically, pay taxes online and be able to track their tax obligations to the budget.

However, despite the growing tendency of trusting relationships with taxpayers and the development of a system of care for taxpayers, foreign tax authorities do not forget about the imperativeness of tax control.

\section{SUMMARY}

To begin, consider the activity on the performance of tax audits conducted in Russia, as disclosed in Table 4.

Table 4. The effectiveness of on-site tax audits in Russia.

\begin{tabular}{|c|c|c|c|c|c|}
\cline { 2 - 6 } & $\mathbf{0 1 . 0 1 . 2 0 1 5}$ & $\mathbf{0 1 . 0 1 . 2 0 1 6}$ & $\mathbf{0 1 . 0 1 . 2 0 1 7}$ & $\mathbf{0 1 . 0 1 . 2 0 1 8}$ & $\mathbf{0 1 . 0 1 . 2 0 1 9}$ \\
\hline $\begin{array}{c}\text { Total number of } \\
\text { on-site tax audits of } \\
\text { individuals }\end{array}$ & 6299 & 4470 & 3449 & 2600 & 1614 \\
\hline $\begin{array}{c}\text { Revealed violations } \\
\begin{array}{c}\text { The share of } \\
\text { inspections in which } \\
\text { violations were }\end{array}\end{array}$ & 6236 & 4399 & 3394 & 2441 & 1571 \\
\hline $\begin{array}{c}\text { revealed to the total } \\
\text { number }\end{array}$ & $98,99 \%$ & $98,41 \%$ & $98,41 \%$ & $93,88 \%$ & $97,34 \%$ \\
\hline
\end{tabular}

It is worth noting that the overall level of detection of offenses in Russia at the stage of on-site inspections is quite large. Comparing five reporting years, it can be concluded that the total number of inspections in Russia is decreasing. Thus, every year the implementation of the principles of tax law and the Concept of planning of field tax audits is demonstrated in the best way. Based on the fact that the number of checks is reduced, several conclusions can be drawn. This suggests that the election of taxpayers' subject to inspections is increasing. 
Secondly, a decrease in the quantitative composition also accompanies a positive qualitative change in the field checks. Reducing the range of attention of the tax authorities, the legislation places greater emphasis on the dangerous in terms of tax offenses of economic entities (Salmina et al., 2015).

At the same time, the effectiveness of tax audits is sometimes reduced or decreased. However, the range of values within which the value of the detected offenses differs is small: only $0.9 \%$. If we analyze the last reporting year, then in 2018 the total number of individuals on-site tax audits was 1614, of which 1571 violations were detected. The efficiency is $97.34 \%$, and this is a high percentage, given the heterogeneity of our regions and the different level of development of the economy and control authorities.

Thus, we can conclude that some foreign trends in tax control could be relevant in Russia. After all, the constant development of forms and methods, as well as the very basis of tax control - the tax base, allows us to constantly improve the entire tax system in Russia, increase tax revenues and reduce the taxpayers' debt (Balabanova Yuliya et al., 2018). Therefore, completing the consideration of the main directions for improving tax control in Russia, as a result of applying the experience of foreign countries, you can make the following suggestions:

a) Increasing attention to improving various methods of tax control, including its initial stage - tax accounting. Reforming can occur through the introduction of a single mandatory identification number for tax purposes, which makes it less dependent on government accounting authorities (Sabitova \& Khafizova, 2015; Artemenko et al., 2017).

b) Strengthening work on indirect methods of tax accounting. So, one of them may be control over the expenses of individuals, which will help to identify tax evasion.

c) Increasing the methods of working with taxpayers in order to increase the tax literacy of the population. The use of forms designed for different age groups and segments of the population. 
The work is performed according to the Russian Government Program of Competitive Growth of Kazan Federal University.

\section{REFERENCES}

Artemenko, D. A., Aguzarova, L. A., Aguzarova, F. S., \& Porollo, E. V. (2017). Causes of tax risks and ways to reduce them. European Research Studies Fournal, 20(3), 453-459. doi: https://www.researchgate.net/ publication/326734521_Causes_of_tax_risks_and_ways_to_reduce_them

Balabanova Yuliya, N., Nugaev Fatih, S., \& Khafizova Aigul, R. (2018). Perspectives of Tax Control Development for Individuals in Russia. Ad AltaJournal of Interdisciplinary Research, 8(1), 31-34.

Elkina, E. N. (2014). The history of tax audits. Agrarian Bulletin of the Urals, 6(124), 140-145.

Gerb, A. A. (2015). Features of the implementation of tax control in the United States. Scientific Almanac, 12-1(14), 103-105.

Mityurnikova, L. A., \& Revyakina, T. Yu. (2013). The tax system as the main regulator of the development of the tax potential of the state (Comparative analysis of the tax systems of Canada, Russia, Japan). Financial Analytics: Problems and Solutions, 5(143), 26-35.

Morozov, M. S. (2009). Foreign experience of increasing tax control. Bulletin of the Association of Universities of Tourism and Service, 2, 68-73.

Sabitova, N. M., \& Khafizova, A. R. (2015). Information technologies as a factor of evolution of tax administration. Mediterranean fournal of Social Sciences, 6(1), 169-173. doi: https://doi.org/10.5901/mjss.2015.v6n1s3p169 
Salmina, S. V., Khafizova, A. R., \& Salmin, I. V. (2015). Arrangement and performance of on-site tax auditing in the Russian federation. Mediterranean Fournal of Social SciencesVolume, 6(3), 732-735. doi: https://doi.org/10.5901/ mjss.2015.v6n3p732

Solovyova, N. E., \& Shevchenko, E. E. (2013). Comparative analysis of the tax administration system of Japan and Russia. Economy and Modern Management: Theory and Practice, 30, 42-49.

Yegorov, E. A. (2017). The direction of improving tax control in Russia with the experience of Japan. Energy of Science, 61-63. 